\title{
QUANTITATIVE EASING EFFECTS ON EQUITY MARKETS - EVENT STUDY EVIDENCE FROM THE US
}

\section{Leoš Šafár, Marianna Siničáková}

\section{Introduction}

After financial crisis in 2008 , both financial and non-financial institutions, governments and monetary authorities as regulators faced great challenges in overcoming recent depression. Although different market participants in different fields reacted and accommodated in their own ways, they relied on monetary authorities more than they did before crisis. Monetary authorities were in position to deliver policies accommodative enough to stimulate economy, or at least reduce damage cumulated during crisis period. From our point of view, first step was pushing interest rates near zero level or lower in order to loosen borrowing conditions. But, on the other hand, monetary authorities approached to changes in legislation in order to prevent situation that caused crisis in the first place. In other words, meeting requirements for getting access to capital become stricter. Once zero-lower bound (ZLB) was reached, and there was no sign of substantial economic recovery and growth in mid-term horizon, central banks moved towards unconventional monetary policies (the Federal Reserve System and later the European Central Bank, besides them, also Bank of England and much sooner bank of Japan implemented these policies) via implementing unconventional instruments. Considering volume, assets included, and time period, the quantitative easing (QE) drags most attention.

This instrument was firstly used by Bank of Japan in order to fight deflation, while effectiveness was questioned among the academics, partially because of some specifics of Japan's financial sector. The European Central Bank (ECB) implemented proper QE back in the beginning of 2015 (QE ended in December 2018). Some unconventional instruments took place in late 2008, however, considering volume and assets included, we do not consider them as a proper QE. In the US, first QE began in 2008 and last programme ended up in 2014, excessing \$4.5tn of assets bought in total under such programmes. While finding robust and strong evidence among the literature about lowering both corporate and government bond yields across the yield curve, considering large volumes of capital used for this policy, participants and assets included and affected, potential spill-overs and topicality, we find it beneficial to examine effects of particular non-standard policy, from different, less examined perspective - on equity markets. In this paper we focus on situation in the US, mainly because of fact, that even though programme has ended, effects on equity markets remain undiscovered, and findings of market reactions to $Q E$ related information could become useful both for profiting or hedging during possible similar situations in the future. For that purpose, we will use the benchmark equity indices as representatives of the equity markets in the US.

This work is structured as follows; firstly, we provide necessary information about unconventional monetary policy and $\mathrm{QE}$ in general. Next, we present review of research of other authors aiming this topic together with description of process of QE in the US. Second chapter present methodology and data used for our empirical analysis. Third chapter presents our results, followed by discussion. Final chapter concludes.

\section{Unconventional Monetary Policy}

Before financial crisis in 2007 and 2008, respectively, standard or conventional monetary policies were oriented mainly on keeping inflation low and stable. This approach seemed secure enough, with no big obstructions in implementing. Main instruments were short-term interest rates, at which funding to banks and interbank markets was 
provided, while impact of this policy on both market interest rates and broader economy was reliably quantified. For setting suitable base interest rates monetary authorities usually used the Taylor-type rule calculations or referred to models based on expectations of future macroeconomic indicators, considering wide macroeconomic data (Woodford, 2001; Orphanides, 2003; Orphanides, 2010; Taylor, 2009; Taylor \& Davradakis, 2006). To simplify, the interest rates were linked mainly to changes in the inflation and the output gap, while this way of handling monetary policy was easy to predict and effective in order to keep inflation from rising (todays' monetary authorities' practices are more based upon more sophisticated methods such as forecast targeting, see e.g. Svensson, 2018).

After economies all over the world witnessed crushing years, new challenges came up for policymakers. Firstly, it was strong trend in implementing actions in order to prevent next bubbles forming in the markets, which logically lead to more regulations and tightening of financial legislation. On the other hand, second great challenge for central bankers was finding the way how to support very slow economic recovery, hence central bankers become very important market participants in almost intraday view.

Setting monetary policy in order to secure sustainable recovery was complicated, at least because of the current interest rates. The interest rates were kept at zero level or close by central banks, as Taylor-type rules indicated because of current state of macroeconomic indicators. Consequently, phenomenon called "zero-lower bound" (ZLB) occurred, regarding to fact, that keeping cash positions bears no interest, hence market interest rates are effectively bounded to zero level. Thus, traditional relationship between base interest rate set up by central bank and market interest rates become obsolete (see e.g. Bernanke et al., 2004; Gagnon et al., 2011; Joyce, 2012; Joyce et al. 2010). In addition, after huge losses that came along with crisis, many market participants, including financial and non-financial sector and other individuals, became much less solvent compared to period before crisis. In other words, the market participants were short of liquidity. Other factor was, that after period of losses, banks were more likely improving their balance sheets rather than providing capital further via lending to private sector. Therefore, at this point, the conventional monetary policies become ineffective: the monetary rules failed as effective instrument used to set appropriate base interest rates, because these rates did not have required effect on market interest rates, while very cautious banks deviated from usual financial intermediation. To sum up, in this situation, well known and usual transmission channel of monetary policy did not work, and monetary authorities were expected to bring something new in order to give some positive stimulus to the markets. Central bankers then reversed this channel and moved towards targeting on quantity variables, in order to set interest rates via fluctuations and changes in bank's reserves with aim to provide enough credit to banks to support lending (Joyce, 2012; Gagnon et al., 2011). As Fratzscher et al. (2017) suggests, besides more standard countercyclical policies, the FED introduced new set of non-standard (often labelled as credit easing) instruments.

For purposes of this paper, we will be dealing only with high profile form of unconventional monetary policy - so called quantitative easing. Reason for this decision lays on the fact that the $Q E$ is the most significant instrument among the other unconventional monetary policy instruments considering volume and spectrum of assets included. The term QE was firstly used in line with Japan's situation that followed real estate bubble burst, and deflationary pressures that consequently occurred in the 1990s. With interest rates at a zero-lower bound (ZLB), the Bank of Japan (BoJ) decided to boost banks' cash reserves by purchasing assets government bonds - from banks. The main idea was that providing cash to banks will support lending across the market and consequently extenuate deflationary pressures, once banks will achieve required level of cash reserves.

\subsection{Quantitative Easing - Proceedings in the US}

Gradually, the QE (QE is also labelled as LargeScale Asset Purchase) as a policy instrument was adopted by the FED, Bank of England and ECB. Bankruptcy of the Lehman Brothers in 2008 showed, that many assets held by banking sector in the US were "toxic" - in other words, with default rating after revision. Distrust of the financial institutions led to stagnation of the credit market. The FED decided to 
approach the QE in order to support the credit market by purchasing mainly these toxic assets - replacing them with cash, from banks' point of view. In November 2008 the FED started purchasing mortgage-backed securities (MBS), government bonds and bonds of government mortgage agencies (it extended the programme in March 2009). So-called QE1 (volume of QE1 was divided as follow: government bonds $\$ 300 \mathrm{bn}$, government mortgage agencies \$200bn, MBS - \$1.25tn) lasted from November 2008 to March 2010. This "first" wave of QE was oriented on supporting bank's health. Nevertheless, the banks were sceptic about uncertain future development, therefore they kept their cash positions instead of transferring money to other subjects - which lead to situation labelled as liquidity trap. Consequently, in November 2010 the FED approached to the next "wave" of quantitative easing - QE2 - with aim to support economy's weak performance by purchasing additional government bonds (total volume of QE2 was $\$ 600 \mathrm{bn}$ ). It was expected, that rising bond prices will encourage interest in capital market (generally speaking - riskier investments), increase domestic demand and support exports after decreasing exchange rate of dollar. The QE2 lasted till Jun 2011 with monthly pace of purchases at $\$ 75 \mathrm{bn}$. In September 2012 the FED announced, that without more intervention, fragile economic recovery could not become substantial, improvement on labour market could not become persistent and inflation would not reach inflation target - at or below $2 \%$. In spite of this doubt, the FED launched third quantitative easing (QE3). The QE3 was firstly kept at monthly pace of $\$ 40 \mathrm{bn}$ MBS purchases, with unspecified time frame. Instead of announcing expected duration of this programme, the FED announced commitment to continue in its policy until substantial recovery on the labour market will be achieved, with respect to the price stability. In addition, in December 2012, the FED started buying government bonds in monthly pace $\$ 45 \mathrm{bn}$ as a consequence of the "Extended Duration Programme". The FED ended QE3 program in October 2014 (Gilchrist, 2014; Weale \& Wieladek 2016).

All mentioned purchases inflated the FED's balance sheet significantly. From the pre-crisis period, when balance-sheet was at a level of $\$ 800 \mathrm{bn}$, it rose to almost $\$ 4.5 \mathrm{tn}$ at the end of the QE programmes. In some point, the central banks decide to unwind their balance sheets, which we consider as a consequence of the $\mathrm{QE}$, also as the policy normalization, and therefore the consequences and the effects of balance-sheet unwinding should be subject of attention regarding the QE. With respect to policy normalization, we mention socalled "taper tantrum" in 2013, when the FED announced reducing monthly pace of purchases by $\$ 10 \mathrm{bn}$ from current $\$ 85 \mathrm{bn}$ every next meeting onwards. This information resonated throughout financial markets strongly, proving strong spill-over effect and disrupted both fixed income and equity trading for some period, causing sell-offs in domestic markets same as in emerging markets' credit and equities (see e.g. MacDonald, 2017; Fratzscher et al., 2017). In September 2017, the FED announced unwinding its balance sheet in moderated monthly pace of $\$ 10 \mathrm{bn}$ of expiring securities (divided as $\$ 4 \mathrm{bn}$ of MBS and $\$ 6 \mathrm{bn}$ of securities, with aim to reach monthly pace of $\$ 20 \mathrm{bn}$ of MBS and $\$ 30 \mathrm{bn}$ of securities, till balance sheet shrinks to $\$ 3$ tn), and logically we consider the effects related to this operation as a potential subject of further and more complex research of the $\mathrm{QE}$.

\subsection{Research Review}

Across the literature, we find that research mainstream linked to the QE topic is oriented on bond yields, while consensus among the authors suggests, that the QE lowered both corporate and government bond yields persistently along the yield curve, generally accepting that impact of the QE on bond yields is first and crucial step for other broader effects. Concentrating specifically on the US, we can find slightly different results using mainly two methodological approaches - VAR (Vector Autoregression) models and their modifications for broader macroeconomic effects, and eventstudy approach for instant effects caused by information about the $\mathrm{QE}$.

Chung et al. (2012) is dealing with the ZLB situation after crisis in the US, but even if authors agree upon that the ZLB was highly anticipated and predicted given the circumstances, they question persistency of the ZLB. Using the DSGE (Dynamic Stochastic General Equilibrium) and VAR models, authors come to different predictions (depending on the model specifications) about how long should the ZLB last. Despite contradictory predictions about the 
ZLB duration, they find the intersections among the models used, suggesting that short-term yields decreased significantly.

Altavilla and Giannone (2014) adopt eventstudy to estimate perceived effects of the UMP on long-term bond yields performing analysis of revisions of predictions of professional forecasters around the announcement and implementation of policy decisions given by the FOMC, the FED respectively, after the crisis. Authors provide results showing significant and persistent drop in long-term bond yields, adding that the information is priced into bonds immediately after the announcement.

Here we would like to point out, that despite the event-study is widely used among the authors (Gagnon et al., 2011; Wright, 2012; Bauer et al., 2014; Swanson, 2011; Joyce et al., 2010), Thornton (2017) proves that the event-study approach and its modifications with the announcements used as events cannot provide statistically significant information about the persistence and durability of effects caused on bond yields by those announcements, therefore this approach cannot be used to examine effectiveness of the QE in its complexity.

Broader study of Hausken and Ncube (2013) examines both effects of the QE on interest rates and yields, respectively, and broader economic effects of the QE using the event-study and the Bayesian Vector Autoregressive (BVAR) methods. Results from the event-studies of Japan, the UK, the US and the EU are in line with other authors - the QE caused drop in yields significantly, affecting the whole yield curve. In addition, authors provide evidence, that the FED and the BoE were more effective in lowering yields compared to the BoJ and the ECB. The BVAR methods were used to examine effects of the QE on the inflation and the GDP (Gross Domestic Product). Authors present that, in general for all four regions, effects of the QE on the GDP were rather limited, or insignificant. On the other hand, in order to push inflation higher, the QE is effective tool in the ZLB according to the BVAR results presented in this study.

Also using the BVAR models, different results are presented in study provided by Weale and Wieladek (2016). The study is dealing with impact of the announcements of large-scale purchases of government bonds on the real GDP and the CPI in the US and the UK. Within their BVAR models author use four different identification schemes, all leaving reactions of the GDP and the CPI unrestricted. Results from this study claim, that in aftermath of financial crisis, both the BoE's and the FED's asset purchases were effective in supporting the GDP. Authors estimate, that the asset purchasing related shock caused by the central bank purchasing government bonds worth $1 \%$ of the nominal GDP has resulted in increasing of $0.62 \%$ of the real GDP and $0.58 \%$ in the CPI (Consumer price index) in the US. For the UK increases are $0.25 \%$ for the real GDP and $0.32 \%$ for the CPI. Study also provides solid explanations of these effects throughout the transmission channels discussed in previous chapter. Similar results for the UK we find in Kapetanios et al. (2012), where authors used the BVAR and VAR models. This study is focused only on the UK and the main challenge for authors is to examine the macroeconomic impact of first round of the QE run by the BoE. They also find both the CPI and GDP positively implied by the QE via short-term yields. Among literature, we witness mainly the VAR, BVAR, regressions and event-studies.

Considering methodological approaches, we find research by D'Amico and King (2013) very specific compared to other studies. Authors used their own approach, they add "supply channel" - not in line with classic transmission channels - to consideration and to calculate the "stock" and "flow" effects as an explanatory part of local-supply channel. The "stock effects" are defined as persistent changes in prices that result from movements along the Treasury demand curves, while the "flow effects" are defined as the response of prices to the ongoing purchase operations and could reflect, on top of the portfolio rebalancing activity due to the outcome of the purchases, impairments in liquidity and functioning, that lead to sluggish price discovery. They are oriented on explaining changes in yields of substitutes to assets directly purchased under the LSAP. Except for reducing yields, results from both the "stock" and "flow" effects are supporting the preferredhabitat theories, which are suggesting that treasuries at a given maturity can be sensitive to the amount of privately held treasury debt available with similar maturity. Term referring to "habits" of investors, meaning they will prefer some type of investment considering mainly duration, because of their portfolio strategy. 
Study results further indicate that, on the days when a security was eligible to be bought, purchases of securities with similar maturities had almost as large effects on its yield as did purchases of the security itself. These results are consistent with Greenwood (2005), Gabaix et al. (2007), Vayanos and Vila (2009), and Greenwood and Vayanos (2010).

Besides larger VAR models, there is rich representation of event-studies among the literature connected to the QE in almost every region/country, but mostly examining effects on the bonds (yields, respectively) or foreign exchange rates. In addition, Henseler (2018) uses the event-study to examine cross sectional variation in non-financial firms, concluding that the announcement returns are positively correlated with leverage and negatively with size of the company. Shah et al. (2018) adds evidence that the $Q E$ caused reduction in the equity risk premium for the S\&P500 using VAR, which led to increase in the equity prices of $9.6 \%$ over the longer observed period (from 1974 to 2017). Also, Su and Hung (2017) argues that the QE had positive effects on the stock markets from 2003 to 2014. Hence, we decided to examine effects of the QE related information to the equity/stock markets from intraday perspective, which we consider easier available compared to the bond markets for small investors or traders. On the other hand, changes in the stock market prices could signalize if the portfolio rebalancing channel caused additional inflows or outflows to equities, even though Fratzscher et al. (2017) argues that the QE had more significant effects in portfolio decision making over the longer term, adding that the information was not fully priced in immediately after the announcement. In other words, aim of this paper is to determine whether the information related to the unconventional monetary policy, provided by monetary authority, has positive or negative impact on the stock markets via examining returns on the benchmark indices on announcement days, while we take into account character of the announcement. To keep our research as useful as possible, we decided to work with announcements of the FED, examining their intraday effect on the benchmark indices using event-study approach. This should represent microeconomic implications, considering that the QE linked information is priced in not only in the bond markets but also in the equity markets immediately, therefore they represent reaction of the market participants to particular information. Examining market reaction to this type of information could either bring profit via opening a position in advance or help to hedge against loses via closing the already opened positions.

\section{Methodology and Data}

To examine effects of announcements on the stock markets, we use the standard event-study methodology to determine the excess returns (see e.g. MacKinlay, 1997). Abnormal returns will be analysed in same time point (day) as the announcement is released (announcements are released usually in the afternoon, while markets close several hours later, which gives us enough time to absorb information contained in particular announcement) using average returns (Brown \& Warner, 1985) calculated from previous sixty days:

$$
\begin{aligned}
& A_{A D}=R_{A D}-\bar{R}_{t} \\
& \bar{R}_{t}=\frac{1}{60} \sum_{t=-60}^{-1} R_{t}
\end{aligned}
$$

where $A_{A D}$ represents the excess return on the announcement day (AD) of the particular index, $R_{A D}$ is return of the particular index on the announcement day calculated as difference between closing prices on the announcement day and the previous day and $\bar{R}_{t}$ is the average return on particular index considering sixty days before announcement. For purposes of this study, we consider $A_{A D}$ as a key indicator that helps us to determine effect of the QE related statements on the equity markets, while persistence of those effects cannot be examined using only this methodology (see Thornton, 2017). We used daily close prices of main equity indices representing the US equity markets (DJIA, S\&P500, NASDAQ, Russell2000), while the returns/changes were calculated as percentages. The returns on announcement days were removed from sample so average returns were calculated without being contaminated by the excess returns on the announcement days. The DJIA index (Dow Jones Industrial Average) represents 30 biggest blue-chip companies in the US, the S\&P500 (Sandard's \& Poor's 500) represents 500 biggest large-cap companies in the US, the Russell2000 represents 2000 small- 
cap companies in the US and the NASDAQ represents 100 biggest non-financial mainly technology companies in the US.

With this indicator we try to approximate how daily returns on the indices deviate on particular announcement day from its average performance during the previous sixty days. Even though persistency of these effects can be questioned, we get solid information about sentiment brought to market participants by the FED, in order to find out if such a policy is positive or negative impulse for the equities, which we consider as a main advantage of this methodology.

In Tab. 1 below we present announcements considered as events, compiled of every single press release of the FED from 2008 to 2017, which contained the QE related information. Table shows what type of meeting or announcement on which particular day (first two columns) provided information linked to which particular QE programme.

\section{Tab. 1: FED's QE related announcements (Part 1)}

\begin{tabular}{|c|c|c|}
\hline Date & Event & Description \\
\hline 13.12.2017 & FOMC Statement & $\begin{array}{l}\text { Continued unwinding balance sheet at monthly pace } \$ 10 \text { billion } \\
\text { from October } 2017 \text {. }\end{array}$ \\
\hline 20.09.2017 & FOMC Statement & $\begin{array}{l}\text { Starting to unwind balance sheet at monthly pace } \$ 10 \text { billion } \\
\text { in October } 2017 .\end{array}$ \\
\hline 14.06.2017 & FOMC Statement & $\begin{array}{l}\text { Announcing, that balance sheet normalization programme will } \\
\text { begin in October } 2017 .\end{array}$ \\
\hline 29.10 .2014 & FOMC Statement & QE3 ends. \\
\hline 18.12.2013 & FOMC Statement & QE3 will be tapered at $\$ 10$ billion monthly pace every meeting. \\
\hline 12.12 .2012 & FOMC Statement & $\begin{array}{l}\text { QE3 expanded: The Fed will continue to purchase } \$ 45 \text { billion } \\
\text { of long-term Treasuries per month but will no longer sterilize } \\
\text { purchases through the sale of short-term treasuries. }\end{array}$ \\
\hline 13.09.2012 & FOMC Statement & $\begin{array}{l}\text { QE3 announced: The Fed will purchase } \$ 40 \text { billion of MBS per } \\
\text { month as long as "the outlook for the labour market does not } \\
\text { improve substantially... in the context of stability." }\end{array}$ \\
\hline 22.08.2012 & $\begin{array}{l}\text { FOMC minutes } \\
\text { released }\end{array}$ & $\begin{array}{l}\text { FOMC members "judged that additional monetary accommodation } \\
\text { would likely be warranted fairly so on..." }\end{array}$ \\
\hline 20.06.2012 & FOMC Statement & $\begin{array}{l}\text { Maturity Extension Program extended: The Fed will continue } \\
\text { to purchase long-term securities and sell short-term securities } \\
\text { through the end of } 2012 \text {. Purchases/sales will continue at the } \\
\text { current pace, about } \$ 45 \text { billion/month. }\end{array}$ \\
\hline 21.09.2011 & FOMC Statement & $\begin{array}{l}\text { Maturity Extension Program (“Operation Twist") announced: } \\
\text { The Fed will purchase } \$ 400 \text { billion of Treasuries with remaining } \\
\text { maturities of } 6 \text { to } 30 \text { years and sell an equal amount with } \\
\text { remaining maturities of } 3 \text { years or less; MBS and agency debt } \\
\text { principal payments will no longer be reinvested in Treasuries, but } \\
\text { instead in MBS. }\end{array}$ \\
\hline 22.06.2011 & FOMC Statement & $\begin{array}{l}\text { QE2 finishes: Treasury purchases will wrap up at the end of } \\
\text { month, as scheduled; principal payments will continue to be } \\
\text { reinvested. }\end{array}$ \\
\hline 03.11 .2010 & FOMC Statement & QE2 announced: Fed will purchase $\$ 600$ billion in Treasuries. \\
\hline 15.10 .2010 & Bernanke Speech & Bernanke reiterates that Fed stands ready to further ease policy. \\
\hline 12.10 .2010 & $\begin{array}{l}\text { FOMC minutes } \\
\text { released }\end{array}$ & $\begin{array}{l}\text { FOMC members' "sense" is that "[additional] accommodation may } \\
\text { be appropriate before long..." }\end{array}$ \\
\hline
\end{tabular}




\begin{tabular}{|c|c|c|}
\hline Date & Event & Description \\
\hline 21.09.2010 & FOMC Statement & $\begin{array}{l}\text { FOMC emphasizes low inflation, which "is likely to remain } \\
\text { subdued for some time before rising to levels the Committee } \\
\text { considers consistent with its mandate." }\end{array}$ \\
\hline 27.08.2010 & Bernanke Speech & $\begin{array}{l}\text { Bernanke suggests role for additional QE "should further action } \\
\text { prove necessary." }\end{array}$ \\
\hline 10.08.2009 & FOMC Statement & $\begin{array}{l}\text { Balance sheet maintained: The Fed will reinvest principal } \\
\text { payments from LSAPs in Treasuries. }\end{array}$ \\
\hline 04.11 .2009 & FOMC Statement & $\begin{array}{l}\text { LSAPs downsized: Agency debt purchases will finish at } \$ 175 \\
\text { billion. }\end{array}$ \\
\hline 23.09.2009 & FOMC Statement & $\begin{array}{l}\text { LSAPs prolonged: Agency debt and MBS purchases will finish } \\
\text { at the end of 2010:Q1. }\end{array}$ \\
\hline 12.08.2009 & FOMC Statement & $\begin{array}{l}\text { LSAPs prolonged: All purchases will finish by the end of October, } \\
\text { not mid-September. }\end{array}$ \\
\hline 18.03.2009 & FOMC Statement & $\begin{array}{l}\text { LSAPs expanded: Fed will purchase } \$ 300 \text { billion in long-term } \\
\text { Treasuries and an additional } \$ 750 \text { and } \$ 100 \text { billion in MBS } \\
\text { and GSE debt, respectively. }\end{array}$ \\
\hline 28.01.2008 & FOMC Statement & Fed stands ready to expand QE and buy Treasuries. \\
\hline 16.12.2008 & FOMC Statement & First suggestion of extending QE to Treasuries by FOMC. \\
\hline 01.12 .2008 & Bernanke Speech & First suggestion of extending QE to Treasuries. \\
\hline 25.11.2008 & FOMC Statement & $\begin{array}{l}\text { LSAPs announced: Fed will purchase } \$ 100 \text { billion in GSE debt } \\
\text { and } \$ 500 \text { billion in MBS. }\end{array}$ \\
\hline
\end{tabular}

Source: own elaboration using data from FED.

Note: Fratzscher et al. (2017) used same announcements in reference period from 2008 to 2010, Sosvilla-Rivero \& Fernández-Fernández (2015) used similar announcements along with ECB announcements.

These announcements from the FED, together with the daily close prices of mentioned indices represented key information and input data for our event-study. While the methodology itself appears simply to use, for proper interpretation and avoiding any misunderstanding, detailed analysis of information provided in the FOMC minutes and statements was needed. On the other hand, clear isolation of the QE related information is not entirely possible. Accepting limitations of this methodology, potential spill-overs to other equity markets will not be examined due to inconsistency in trading hours.

However, based on studies examining longterm effects of the QE on the equity markets (see e.g. Shah et al., 2018; Su \& Hung, 2017; Fratzscher et al., 2017), our main hypothesis was, that the major equity gauges will respond positively on particular announcement day if the QE is announced or expanded with respect to time or duration, in compared to other announcement days where such an information is not provided. Consequently, we assume the equity indices would react negatively if announcement consists information linked to tapering or normalization of monetary policy.

\section{Results}

In Tab. 2 below we present calculated excess returns on the observed indices on particular announcement days (events), while the returns above one percent or below minus one percent are shown bold. We can observe more volatile reactions during the $2008-2010$ period, which we consider as a fragile crisis and post crisis period, when the monetary authority (FED) was becoming even closely watched by the market participants - also starting with massive support for damaged economy. These initial overreactions (mostly due to fresh crisis sentiment and the FED under adaptation 
process) diminished mostly over the reference period as stable and foreseeable forward guidance took place (see e.g. Yu, 2018; Xing, 2018).

In average, the excess returns on the indices during the reference period on announcement days were positive: DJIA $+0.12 \%$, NASDAQ $+0.16 \%$, RUSSELL2000 +0.04\%, S\&P500 $+0.16 \%$, which is slightly above the average daily returns over the reference period except from RUSSELL2000 (DJIA $+0.03 \%$, NASDAQ +0.05\%, RUSSELL2000 +0.04\%,
S\&P500 +0.03\%), but we do not consider this interpretation as significant enough to support our main assumptions. Firstly, average returns are small and secondly, there are some specific announcements in our sample that needs individual approach. In other words, as mentioned earlier, the character of announcement would be important.

On December $1^{\text {st }}, 2008$, the FED chairman, Ben Bernanke firstly suggested expanding FED's purchases to Treasuries (debt obligations issued by the US government),

\section{Tab. 2: Excess returns of main indices on announcements days}

\begin{tabular}{|c|c|c|c|c|c|}
\hline Date & Event & DJIA & NASDAQ & RUSSEL2000 & S\&P500 \\
\hline 13.12.2017 & FOMC Statement & $0.17 \%$ & $0.09 \%$ & $0.47 \%$ & $-0.15 \%$ \\
\hline 20.09.2017 & FOMC Statement & $0.11 \%$ & $-0.14 \%$ & $0.32 \%$ & $0.02 \%$ \\
\hline 14.06 .2017 & FOMC Statement & $0.18 \%$ & $-0.50 \%$ & $-0.64 \%$ & $-0.15 \%$ \\
\hline 29.10 .2014 & FOMC Statement & $-0.25 \%$ & $-0.41 \%$ & $-0.32 \%$ & $-0.20 \%$ \\
\hline 18.12 .2013 & FOMC Statement & $1.78 \%$ & $1.04 \%$ & $1.25 \%$ & $1.58 \%$ \\
\hline 12.12 .2012 & FOMC Statement & $0.02 \%$ & $-0.20 \%$ & $-0.62 \%$ & $0.09 \%$ \\
\hline 13.09.2012 & FOMC Statement & $1.48 \%$ & $1.23 \%$ & $1.16 \%$ & $1.53 \%$ \\
\hline 22.08 .2012 & FOMC minutes released & $-0.32 \%$ & $0.09 \%$ & $-0.44 \%$ & $-0.09 \%$ \\
\hline 20.06 .2012 & FOMC Statement & $-0.05 \%$ & $0.13 \%$ & $-0.19 \%$ & $-0.10 \%$ \\
\hline 21.09 .2011 & FOMC Statement & $-2.41 \%$ & $-1.97 \%$ & $-3.45 \%$ & $-2.85 \%$ \\
\hline 22.06 .2011 & FOMC Statement & $-0.66 \%$ & $-0.65 \%$ & $-0.78 \%$ & $-0.63 \%$ \\
\hline 03.11 .2010 & FOMC Statement & $0.12 \%$ & $0.07 \%$ & $0.09 \%$ & $0.23 \%$ \\
\hline 15.10 .2010 & Bernanke Speech & $-0.45 \%$ & $1.17 \%$ & $-0.49 \%$ & $0.04 \%$ \\
\hline 12.10 .2010 & FOMC minutes released & $-0.08 \%$ & $0.43 \%$ & $0.06 \%$ & $0.19 \%$ \\
\hline 21.09 .2010 & FOMC Statement & $-0.07 \%$ & $-0.43 \%$ & $-0.94 \%$ & $-0.40 \%$ \\
\hline 27.08 .2010 & Bernanke Speech & $1.64 \%$ & $1.71 \%$ & $2.90 \%$ & $1.68 \%$ \\
\hline 10.08 .2010 & FOMC Statement & $-0.53 \%$ & $-1.22 \%$ & $-1.93 \%$ & $-0.60 \%$ \\
\hline 04.11 .2009 & FOMC Statement & $0.21 \%$ & $-0.16 \%$ & $-1.34 \%$ & $0.01 \%$ \\
\hline 23.09.2009 & FOMC Statement & $-1.06 \%$ & $-0.95 \%$ & $-1.50 \%$ & $-1.25 \%$ \\
\hline 12.08.2009 & FOMC Statement & $1.14 \%$ & $1.23 \%$ & $1.55 \%$ & $0.99 \%$ \\
\hline 18.03 .2009 & FOMC Statement & $1.51 \%$ & $2.12 \%$ & $3.79 \%$ & $2.34 \%$ \\
\hline 28.01.2009 & FOMC Statement & $2.56 \%$ & $3.63 \%$ & $3.89 \%$ & $3.46 \%$ \\
\hline 16.12.2008 & FOMC Statement & $4.42 \%$ & $5.78 \%$ & $7.20 \%$ & $5.46 \%$ \\
\hline 01.12 .2008 & Bernanke Speech & $-7.37 \%$ & $-8.39 \%$ & $-11.22 \%$ & $-8.46 \%$ \\
\hline 25.11.2008 & FOMC Statement & $0.87 \%$ & $0.21 \%$ & $2.24 \%$ & $1.24 \%$ \\
\hline
\end{tabular}


which immediately caused portfolio rebalancing towards mentioned treasuries from the equities, therefore we have seen significant sell-off in the equities on that announcement day. Another catalyst for following drop was information about the economy (macroeconomic data, such as GDP) contained in his speech, which were negative (negative macro economy outlook and revised-down macro economy data). If we exclude this particular announcement day from our dataset, we can observe significant average positive returns: DJIA $+0.43 \%$, NASDAQ $+0.51 \%$, RUSSEL2000 $+0.51 \%$, S\&P500 $+0.52 \%$. Out of the 25 (24 if above mentioned announcement is excluded) observed announcements, majority of reactions were positive: DJIA 14, NASDAQ 14, RUSSEL2000 12, S\&P500 14. Average upside on announcement days with positive market reaction was: DJIA +1.16\%, NASDAQ +1.35\%, RUSSEL $+2.08 \%$, S\&P500 $+1.35 \%$. On the other hand, average declines on equity indices if market reaction was negative are significantly smaller: DJIA $-0.39 \%$, NASDAQ $-0.66 \%$, RUSSEL2000 - $1.05 \%$, S\&P500 -0.40\%. To sum up these basic findings from trading perspective, opening a long position on DJIA, NASDAQ and S\&P500 (RUSSEL2000 gives us only 50\% winning chance which we consider ineffective) on FED announcement day would give us $58 \%$ probability of $1.16 \%$ gain on DJIA, $1.35 \%$ on NASDAQ and $1.35 \%$ on S\&P500 respectively, while we face downside risk of $-0.39 \%$ on DJIA, $-0.66 \%$ on NASDAQ and $-0.40 \%$ on S\&P500, respectively, in $42 \%$ of situations. These results lead to conclusion, that the profitable trading strategy can take place in the future under specific circumstances.

In order to stick to our main hypothesis, that the announcements linked to announcing and prolonging (with respect to time or duration) the QE programmes should cause positive reaction on the equity indices, we identified 12 announcements containing such an information (Tab. 3 - group 1). Rest of the announcements (Tab. 3 - group 2) contained different type of the QE linked information (including tapering and policy normalization).

From Tab. 3 we see that the average excess return on group 1 announcement days remains in highly positive range, where DJIA, NASDAQ and RUSSEL2000 reacted positively in $75 \%$ of

\section{Tab. 3: Grouped announcements days}

\begin{tabular}{c|r|r|r|r|r|r|r|r|r}
\multicolumn{1}{c|}{ Group 1 } & \multicolumn{5}{|c}{ Group 2 } \\
\hline Date & DJIA & NASDAQp & RUSSEL2000p & S\&P500p & Date & DJIA & NASDAQ & RUSSEL2000 & S\&P500 \\
\hline 12.12 .2012 & $-0.02 \%$ & $-0.28 \%$ & $-0.67 \%$ & $0.04 \%$ & 13.12 .2017 & $0.33 \%$ & $0.20 \%$ & $0.55 \%$ & $-0.05 \%$ \\
\hline 13.09 .2012 & $1.55 \%$ & $1.33 \%$ & $1.30 \%$ & $1.63 \%$ & 20.09 .2017 & $0.19 \%$ & $-0.08 \%$ & $0.35 \%$ & $0.06 \%$ \\
\hline 20.06 .2012 & $-0.10 \%$ & $0.02 \%$ & $-0.30 \%$ & $-0.17 \%$ & 14.06 .2017 & $0.22 \%$ & $-0.41 \%$ & $-0.59 \%$ & $-0.10 \%$ \\
\hline 03.11 .2010 & $0.24 \%$ & $0.27 \%$ & $0.32 \%$ & $0.37 \%$ & 29.10 .2014 & $-0.18 \%$ & $-0.33 \%$ & $-0.27 \%$ & $-0.14 \%$ \\
\hline 12.10 .2010 & $0.09 \%$ & $0.65 \%$ & $0.37 \%$ & $0.38 \%$ & 18.12 .2013 & $1.84 \%$ & $1.15 \%$ & $1.33 \%$ & $1.66 \%$ \\
\hline 27.08 .2010 & $1.65 \%$ & $1.65 \%$ & $2.83 \%$ & $1.66 \%$ & 22.08 .2012 & $-0.23 \%$ & $0.21 \%$ & $-0.34 \%$ & $0.02 \%$ \\
\hline 23.09 .2009 & $-0.83 \%$ & $-0.69 \%$ & $-1.18 \%$ & $-1.01 \%$ & 21.09 .2011 & $-2.49 \%$ & $-2.01 \%$ & $-3.68 \%$ & $-2.94 \%$ \\
\hline 12.08 .2009 & $1.30 \%$ & $1.47 \%$ & $1.79 \%$ & $1.15 \%$ & 22.06 .2011 & $-0.66 \%$ & $-0.67 \%$ & $-0.81 \%$ & $-0.65 \%$ \\
\hline 18.03 .2009 & $1.23 \%$ & $1.99 \%$ & $3.48 \%$ & $2.09 \%$ & 15.10 .2010 & $-0.29 \%$ & $1.37 \%$ & $-0.22 \%$ & $0.20 \%$ \\
\hline 28.01 .2009 & $2.46 \%$ & $3.55 \%$ & $3.83 \%$ & $3.36 \%$ & 21.09 .2010 & $0.07 \%$ & $-0.28 \%$ & $-0.79 \%$ & $-0.26 \%$ \\
\hline 16.12 .2008 & $4.20 \%$ & $5.41 \%$ & $6.69 \%$ & $5.14 \%$ & 10.08 .2010 & $-0.51 \%$ & $-1.24 \%$ & $-2.00 \%$ & $-0.60 \%$ \\
\hline 25.11 .2008 & $0.43 \%$ & $-0.50 \%$ & $1.46 \%$ & $0.66 \%$ & 04.11 .2009 & $0.31 \%$ & $-0.09 \%$ & $-1.31 \%$ & $0.10 \%$ \\
\hline Average & $1.02 \%$ & $1.24 \%$ & $1.66 \%$ & $1.27 \%$ & - & $-0.12 \%$ & $-0.18 \%$ & $-0.65 \%$ & $-0.22 \%$ \\
\hline
\end{tabular}

Source: own elaboration using daily close prices from Investing.com.

Note: Announcement made on December 1st, 2008 consisted first and unprecedent information about QE, which caused massive portfolio rebalancing towards fixed income from equities, we consider as an outlier hence we do not include it. 
occasions, and S\&P500 returned positively on $83.33 \%$ of observed days. In comparison to the second group, where average excess returns fell into negative range, we can conclude that these results are in line with our hypothesis, that the equity indices tend to react positively on announcing, prolonging or expanding the QE programmes linked information (Note: separate Mann-Witney U-tests for each index indicated rejecting null hypothesis, that the groups 1 and 2 are equal on $95 \%$ confidence level; p-values: DJIA 0.019, NASDAQ 0.016, RUSSEL2000 0.004, S\&P500 0.006. Wilcoxon signed rank tests for group 1 indices indicated rejecting null hypothesis that the medians are equal to zero in favour of alternative hypothesis that medians are above zero; $p$-values: DJIA 0.010, NASDAQ 0.021, RUSSEL2000 0.010, S\&P500 0.006).

Additionally, if we take a closer look at the last three announcements in our dataset (June, September and December of 2017) which contains information about the "tapering", or shrinking inflated balance sheet, we see mixed returns, without possibility of clear interpretation, where only the DJIA stayed in positive zone after all three announcements (average $+0.15 \%$ ). Logically, we consider these tapering linked information as a part of the QE, therefore we add them to our dataset. Based on those (only three) included observations of tapering-linked announcements, we cannot prove nor deny our assumption about negative reactions following such information. If history provides some guidance, we already faced one significant tapering contained announcement in December $18^{\text {th }}, 2013$, when initial reaction was positive: DJIA +1.84\%, NASDAQ +1.15\%, RUSSEL2000 +1.33\%, S\&P500 +1.66\%, which is against our assumption, that the tapering (or policy normalization) linked information should cause negative initial reaction on the equity markets. However, after such a positive initial reaction, consequently, we faced so-called "taper tantrum", which lead to sell-offs in bonds, equities and commodities, with effects spilledover also to the emerging markets. Back then it was unprecedented move from the FED (also inevitable), which triggered mentioned sell-offs, while in today's environment we have even clearer forward guidance and communication policy from the FED. Anyway, we do not see straightforward positive or negative reactions, and we consider the equity market participants not fully accommodated to this policy. If we remove those three announcements from our sample, we get even more positive reactions in average, which is in favour of previous assumption that the QE related information caused positive reactions on the equity markets.

Another more volatile announcement came in September 21st, 2011, when the FOMC statement revealed "operation twist" programme. The equity indices fell sharply, from our perspective because of same reason as in the 2008's announcement - market participants shifted their portfolios from the equities towards the mortgage backed securities (MBS), while after negative initial market reaction, positive returns followed. But if we look at August 27th, 2010, when Bernanke mentioned additional (or expanded) QE only as an option that should take place later, the initial reaction of market participants was very positive again not only on the stock markets, but also on bonds and commodities.

This leads us to conclusion, that if we exclude unanticipated and initial announcements of the QE programmes that cause rebalancing of investors' portfolios from the equities to other types of assets, equity markets tend to react positively on the QE linked announcements, to prolongation or expansion with respect to time or duration, respectively.

\section{Discussion}

Based on the results, we consider effects of the QE announcements on the equities as positive, which is in line with studies examining the longterm relationship and effects such as Chen et al. (2012), Fratzscher et al. (2017), Shah et al. (2018) or Su and Hung (2017). However, from short-term or trading perspective, we found some implications that require further explanation. Firstly, we can expect positive excess returns on the stock indices, only when announcement is containing information about preservation, expanding, or prolonging current programme. Realizing long term positive effect of the QE on the equities, additional reassuring from such an announcement that the FED will not change its' path of the QE cause positive actions. On the other hand, on the announcement introducing new $\mathrm{QE}$ type programme (announcement containing initial information about a new programme) we can expect sell-off in equities, which is caused by rebalancing the portfolios towards 
assets directly linked to the programme being announced. This, even from the short-term perspective, supports the portfolio rebalancing channel, broadly discussed and examined in literature from long-term perspective (see e.g. Hausken \& Ncube, 2013; Krishnamurthy \& Vissing-Jorgensen, 2011; Joyce et al., 2011; Gertler \& Karadi, 2011). In the background of this transmission channel we also see the fact that investors' taste for assets that are becoming more expensive, with lower yield, will decrease, and they will seek higher yield among the riskier assets such as equities. Rebalancing in broader way may also lead to spill-overs when agents seek cheaper or similar assets abroad (see e.g. Falagiarda et al., 2015). To conclude, sellers of assets bought under the QE will rebalance their portfolios towards other assets (Gambetti \& Musso, 2017).

Another finding is, that in general we can observe decreasing trend in the volatility over the time. It could be the result, inter alia, of two factors; firstly, stable and robust demand in the credit market, and secondly very stable, continuous and consistent narrative from the FED officials. In other words, after volatile period from 2008 to 2010 , where the new form of forward guidance was being implemented (and the signalling channel took place), the market participants were getting used to forward guidance policy which has resulted in mixed reaction. Consequently, firm FEDs commitment was translated as readiness to continue with high accommodative, non-standard instruments in order to support the economy, in other words, positive. On the other hand, from 2010 onwards, we faced much muted market reactions. Partially because the market participants were oriented mostly on broader economic recovery. The monetary policy was supportive, and the volatility in general suppressed. This is in line with very popular "trade" during the reference period - shorting volatility (see e.g. Ghosh \& Saggar, 2017; Xing, 2018).

The signalling channel, we consider as very important both from longer perspective (Hausken \& Ncube, 2013; Bhattarai et al., 2015; Bernanke, 2004; Eggertsson \& Woodford, 2003) and short-term perspective if we take into account the market participants' expectations, that the short-term interest rates (yields respectively) will remain low in the future (based on the communication strategy provided by central bank - forward guidance), we can observe bidding down yields on longterm securities, and also pushing up equity prices (mainly because of future earnings expectations). Putting this into context with our second assumption, that the tapering-linked information should negatively affect equity performance, we do not find significant evidence from our last three observed announcements, respectively, announcements were followed by mixed reactions. On the other hand, after initial (and unprecedented) announcement about the tapering (December $18^{\text {th }}, 2013$ ) we observed very positive returns on the equity indices again in favour of the portfolio rebalancing transmission channel, however it signalled withdrawing from the extremely supportive monetary policy which lead to significant sell-offs on various assets over next quarter. Again, here we mention the signalling channel, because after such volatile period caused by this policy change, recently we faced much smoother and softer communication of tapering from the FED, with more time to adapt and smaller initial monthly amounts of unwinding with gradual rising, using "autopilot" approach. We put into context, that mixed reactions are partially result of market participants' memory of the "taper tantrum" and partially of much softer announcing and approach from the FED. However, still we consider the tapering (mostly the unwinding of balance sheet) in some way as an unprecedented policy, which would need further research once the unwinding process will be over.

\section{Conclusion}

In this paper we focused on the initial market reaction on the equity markets after the Federal Reserve's QE linked announcement. Adopting the event-study approach previously robustly used among other authors with respect to the QE, and announcements selected from every press release and the FOMC minutes, we calculated excess returns on the major equity indices in the US. Our results suggest, that except from initial (unprecedented and unexpected) announcement of the QE, opening long position on other announcement days would bring profit with $58 \%$ probability $(+1.16 \%$ on DJIA, $+1.35 \%$ on NASDAQ, $+1.35 \%$ on S\&P500), while in $42 \%$ of situations we face downside risk $(-0.39 \%$ on DJIA, $-0.66 \%$ on NASDAQ, $-0.40 \%$ on S\&P500). We conclude that prolonging, preserving or expanding current 
programme has positively affected examined the equity indices, while initial announcing causes declines in the equity markets. These findings we found consistent with the portfolio rebalancing and signalling transmission channels functioning. As far as we consider the tapering and balance sheet unwinding as a process related to the $\mathrm{QE}$ programmes, we found no significant evidence of straightforward reaction of the equities, mainly because of short unwinding period included in our empirical study. We also consider the unwinding of balance sheet as unprecedented to some extent, therefore further research will need to be done after the unwinding process is over. Taking into account difficulty to isolate effects considered as a reaction only to the QE linked information, because of the complexity of statements and announcements made by the FED, we consider these results significant from intraday (or short-term) perspective. Results and interpretations should also provide information for policymakers, in order to avoid unwanted market reactions in future, or to place their forward guidance in more effective way. Realizing currently ended the QE in the European Union, we believe these results could be used in some way as a guidance for examining the ECB's announcement respecting differences between market conditions in the US and the EU.

\section{References}

Altavilla, C., \& Giannone, D. (2017). The Effectiveness of Non-Standard Monetary Policy Measures: Evidence from Survey Data. Journal of Applied Econometrics, 32(5), 952-964. https://doi.org/10.1002/jae.2559.

Bauer, M. D., Rudebusch, G. D., \& Wu, J. C. (2014). Term premia and inflation uncertainty: empirical evidence from an international panel dataset: comment. The American Economic Review, 104(1), 323-337. https://doi. org/10.1257/aer.104.1.323.

Bernanke, B., Reinhart, V., \& Sack, B. (2004). Monetary policy alternatives at the zero bound: An empirical assessment. Brookings papers on economic activity, 2004(2), 1-100. https://doi.org/10.1353/eca.2005.0002.

Bhattarai, S., Eggertsson, G. B., \& Gafarov, B. (2015). Time consistency and the duration of government debt: A signalling theory of quantitative easing (No. w21336). National
Bureau of Economic Research. https://doi. org/10.3386/w21336.

Brown, S. J., \& Warner, J. B. (1985). Using daily stock returns: The case of event studies. Journal of Financial Economics, 14(1), 3-31. https://doi.org/10.2866/478673.

Chen, H., Cúrdia, V., \& Ferrero, A. (2012). The macroeconomic effects of large-scale asset purchase programmes. The Economic Journal, 122(564). F289-F315. https://doi. org/10.1111/j.1468-0297.2012.02549.x.

Chung, H., Laforte, J. P., Reifschneider, D., \& Williams, J. C. (2012). Have we underestimated the likelihood and severity of zero lower bound events? Journal of Money, Credit and Banking, 44(s1), 47-82. https://doi.org/10.1111/j.15384616.2011.00478.x.

D'Amico, S., \& King, T. B. (2013). Flow and stock effects of large-scale treasury purchases: Evidence on the importance of local supply. Journal of Financial Economics, 108(2), 425-448. https://doi.org/10.1016/j.jfineco.2012.11.007.

Eggertsson, G. B., \& Woodford, M. (2003). The Zero Bound on Interest Rates and Optimal Monetary Policy. Brookings papers on economic activity, (1), 139-211.

Falagiarda, M., McQuade, P., \& Tirpák, M. (2015). Spillovers from the ECB's nonstandard monetary policies on non-euro area EU countries: evidence from an event-study analysis [ECB Working Paper No. 1869]. https://doi.org/10.2866/676909.

Fratzscher, M., Lo Duca, M., \& Straub, R. (2017). On the international spillovers of US quantitative easing. The Economic Journal, 128(608), 330-377. https://doi.org/10.1111/ ecoj.12435.

Gabaix, X., Krishnamurthy, A., \& Vigneron, O. (2007). Limits of Arbitrage: Theory and Evidence from the Mortgage Backed Securities Market. The Journal of Finance, 62(2), 557-595. https://doi.org/10.1111/j.15406261.2007.01217.x.

Gagnon, J., Raskin, M., Remache, J., \& Sack, B. (2011). The financial market effects of the Federal Reserve's large-scale asset purchases. International Journal of Central Banking, 7(1), 3-43. https://doi.org/10.2139/ ssrn.1952095.

Gambetti, L., \& Musso, A. (2017). The macroeconomic impact of the ECB's expanded asset purchase programme (APP).

Gertler, M., \& Karadi, P. (2011). A model of unconventional monetary policy. Journal of 
monetary Economics, 58(1), 17-34. https://doi. org/10.1016/j.jmoneco.2010.10.004.

Ghosh, S., \& Saggar, M. (2017). Volatility spillovers to the emerging financial markets during taper talk and actual tapering. Applied Economics Letters, 24(2), 122-127. https://doi. org/10.1080/13504851.2016.1170923.

Gilchrist, S., Yue, V., \& Zakrajsek, E. (2014, November). US monetary policy and foreign bond yields. In 15th Jacques Polak Annual Research Conference hosted by the IMF, Washington, November (pp. 13-14).

Greenwood, R. (2005). Short-and longterm demand curves for stocks: theory and evidence on the dynamics of arbitrage. Journal of Financial Economics, 75(3), 607-649. https://doi.org/10.1016/j.jfineco.2004.03.007.

Greenwood, R., \& Vayanos, D. (2010). Price pressure in the government bond market. The American Economic Review, 100(2), 585590. https://doi.org/10.1257/aer.100.2.585.

Hausken, K., \& Ncube, M. (2013). Quantitative Easing and its Impact in the US, Japan, the UK and Europe. Springer Briefs in Economics. https://doi.org/10.1007/978-14614-9646-5.

Joyce, M., Lasaosa, A., Stevens, I., \& Tong, M. (2010). The financial market impact of quantitative easing [Bank of England Working Paper No. 393]. https://doi.org/10.2139/ ssrn.1638986.

Joyce, M., Lasaosa, A., Stevens, I., \& Tong, M. (2011). The financial market impact of quantitative easing in the United Kingdom. International Journal of Central Banking, 7(3), 113-161.

Joyce, M., Miles, D., Scott, A., \& Vayanos, D. (2012). Quantitative easing and unconventional monetary policy - an introduction. The Economic Journal, 122(564). https://doi. org/10.1111/j.1468-0297.2012.02551.x.

Kapetanios, G., Mumtaz, H., Stevens, I., \& Theodoridis, K. (2012). Assessing the economy-wide effects of quantitative easing. The Economic Journal, 122(564), F316-F347. https://doi.org/10.1111/j.1468-0297.2012.02555.x.

Krishnamurthy, A., \& Vissing-Jorgensen, A. (2011). The effects of quantitative easing on interest rates: channels and implications for policy (No. w17555). National Bureau of Economic Research. https://doi.org/10.3386/ w17555.

MacDonald, M. (2017). International capital market frictions and spillovers from quantitative easing. Journal of International Money and Finance, 70, 135-156. https://doi.org/10.1016/j. jimonfin.2016.08.003.

MacKinlay, A. C. (1997). Event studies in economics and finance. Journal of Economic Literature, 35(1), 13-39.

Orphanides, A. (2003). Historical monetary policy analysis and the Taylor rule. Journal of Monetary Economics, 50(5), 983-1022. https://doi.org/10.1016/S0304-3932(03)00065-5.

Orphanides, A. (2010). Taylor rules. In Monetary Economics (pp. 362-369). Palgrave Macmillan UK. https://doi. org/10.1057/9780230280854_39.

Shah, I., Schmidt-Fischer, F., \& Malki, I. (2018). The portfolio balance channel: an analysis on the impact of quantitative easing on the US stock market [Bath Economics Research Working Papers No. 74/18]. Bath: University of Bath.

Sosvilla-Rivero, S., \& FernándezFernández, N. (2016). Unconventional monetary policy and the dollar-euro exchange rate: first results from time-series analysis. Applied Economics Letters, 23(10), 732-735. https://doi.org/10.1080/13504851.2015.1102841.

Su, J. B., \& Hung, K. (2017). The assessment of the United States quantitative easing policy: Evidence from global stock markets. International Journal of Finance \& Economics, 22(4), 319-340. https://doi. org/10.1002/ijfe.1590.

Svensson, L. E. (2018). Monetary policy and macroprudential policy: Different and separate? Canadian Journal of Economics/ Revue canadienne d'économique, 51(3), 802827. https://doi.org/10.1111/caje.12345.

Swanson, E. T. (2011). Let's twist again: a high-frequency event-study analysis of operation twist and its implications for QE2. Brookings Papers on Economic Activity, 2011(1), 151-188. https://doi.org/10.1353/ eca.2011.0006.

Taylor, J. B. (2009). The financial crisis and the policy responses: An empirical analysis of what went wrong (No. w14631). National Bureau of Economic Research. https://doi. org/10.3386/w14631.

Taylor, M. P., \& Davradakis, E. (2006). Interest rate setting and inflation targeting: Evidence of a nonlinear Taylor rule for the United Kingdom. Studies in Nonlinear Dynamics \& Econometrics, 10(4). https://doi. org/10.2202/1558-3708.1359. 


\section{Finance}

Thornton, D. L. (2017). Effectiveness of QE: An assessment of event-study evidence. Journal of Macroeconomics, 52, 56-74. https://doi.org/10.1016/j.jmacro.2017.03.001.

Vayanos, D., \& Vila, J. L. (2009). A preferred-habitat model of the term structure of interest rates (No. w15487). National Bureau of Economic Research. https://doi.org/10.3386/ w15487.

Weale, M., \& Wieladek, T. (2016). What are the macroeconomic effects of asset purchases? Journal of Monetary Economics, 79, 81-93. https://doi.org/10.1016/j.jmoneco.2016.03.010.

Woodford, M. (2001). The Taylor rule and optimal monetary policy. The American Economic Review, 91(2), 232-237. https://doi. org/10.1257/aer.91.2.232.

Wright, J. H. (2012). What does monetary policy do to long-term interest rates at the zero lower bound? The Economic Journal, 122(564). https://doi.org/10.1111/j.1468-0297. 2012.02556.x.
Xing, V. (2018). Yield Curve Flattening a Symptom of Ineffective Policy Tightening [MPRA Paper No. 84471].

$\mathrm{Yu}, \mathrm{H}$. (2018). US Quantitative Easing Policies: Their Effect on the Global Bond Markets (Doctoral dissertation, Lincoln University).

Ing. Leoš Šafár Technical University of Košice Faculty of Economics Department of Finance Slovakia leos.safar@tuke.sk

doc. Ing. Marianna Siničáková, Ph.D. Technical University of Košice Faculty of Economics Department of Finance Slovakia marianna.sinicakova@tuke.sk 


\section{Abstract}

\section{QUANTITATIVE EASING EFFECTS ON EQUITY MARKETS - EVENT STUDY EVIDENCE FROM THE US}

\section{Leoš Šafár, Marianna Siničáková}

In this paper we examine effects of the QE related statements made by the FED on major equity indices in the US. We consider days, when announcements had been made, as events for the event-study. We approach this methodology with aim to calculate excess returns on particular announcement day for Dow Jones Industrial Average, Standard's \& Poor's 500, NASDAQ and Russell2000. Admitting complexity of those statements, and difficulty to isolate effects linked only to QE related information, we analysed statements individually, to be able to extrapolate deviations more accurately. Results indicate positive excess returns (above average performance over previous 60 days) on each index from 2008 to 2017 in average, while on some specific announcements, excess returns fell to negative range, which could be explained as misunderstanding of reaction function or active portfolio rebalancing towards assets directly influenced by the programme mentioned in the particular announcement. Considering also multiplicity, for DJIA, NASDAQ and $S \& P 500$ we conclude, that positive reactions follow especially information linked to prolongation or expansion of existing QE programme, while on the other hand initial information about QE cause mentioned portfolio rebalancing from equities towards other assets (RUSSEL2000 did not signal particular direction in line with announcement days' information). We can also conclude that even if tapering linked information are considered as a part of the QE programmes, we did not find significant evidence of neither positive nor negative reaction on particular tapering-linked announcements. We add on, that the tapering and balance sheet unwinding are unprecedented to some extent, and therefore require further research, especially in current environment where such policy normalization is widely discussed.

Key Words: Quantitative easing, event-study, monetary policy, equity markets.

JEL Classification: E520, G140.

DOI: 10.15240/tul/001/2019-2-012 